\title{
Pengembangan Buku Cerita Berseri dengan Tema Altruisme untuk Pembelajaran Cerita Rakyat
}

\author{
Puspa Zanuar Asmaranty ${ }^{1}$, Muakibatul Hasanah ${ }^{1}$, Heri Suwignyo ${ }^{1}$ \\ ${ }^{1}$ Pendidikan Bahasa Indonesia-Universitas Negeri Malang
}

\section{INFO ARTIKEL}

\section{Riwayat Artikel:}

Diterima: 02-07-2019

Disetujui: 23-10-2019

\section{Kata kunci:}

serial story books; altruism;

folklore;

buku cerita berseri,

altruisme;

cerita rakyat

\author{
Alamat Korespondensi: \\ Puspa Zanuar Asmaranty \\ Pendidikan Bahasa Indonesia \\ Universitas Negeri Malang \\ Jalan Semarang 5 Malang \\ E-mail: puspazanuar.pz@gmail.com
}

\begin{abstract}
ABSTRAK
Abstract: This study aims to develop a serial storybook with the theme of altruism for folklore learning. This study uses a 4D research and development model which consists of four steps, namely defining, designing, developing, and disseminating. This research produced four series of Samas books, namely (1) Samas and the Three-Color Giant, (2) Samas and the Youngest Southeast Mountain, (3) Samas and Two-Headed Maleo Birds, and (4) Samas and Stone-Humans. The results of the validity test show that the qualified product is feasible and ready to be implemented. Readability test results indicate that the product has a high level of readability. The effectiveness test results show that the product is effectively used in folklore learning.

Abstrak: Penelitian ini bertujuan mengembangkan buku cerita berseri dengan tema altruisme untuk pembelajaran cerita rakyat. Penelitian ini menggunakan model penelitian dan pengembangan $4 D$ yang terdiri atas empat langkah, yaitu pendefinisian, perancangan, pengembangan, dan diseminasi. Penelitian ini menghasilkan empat seri buku Samas, yaitu (1) Samas dan Raksasa Tiga Warna, (2) Samas dan Si Bungsu Gunung Tenggara, (3) Samas dan Burung Maleo Berkepala Dua, dan (4) Samas dan Manusia-Manusia Batu. Hasil uji validitas menunjukkan bahwa produk berkualifikasi layak dan siap diimplementasikan. Hasil uji keterbacaan menunjukkan bahwa produk memiliki tingkat keterbacaan tinggi. Hasil uji keefektifan menunjukkan bahwa produk efektif digunakan dalam pembelajaran cerita rakyat di SMPN 18 Malang.
\end{abstract}

Cerita memiliki peran penting untuk menanamkan nilai kebajikan pada diri anak. Penanaman nilai kebajikan tersebut dapat berlangsung secara efektif apabila diberikan melalui cerita yang disukai oleh anak. McGee (1995) menyatakan bahwa guru percaya bahwa anak-anak lebih cenderung mencintai sastra jika mereka membaca buku-buku berkualitas. Pendapat McGee tersebut sejalan dengan Kurniawan (2009) menyatakan bahwa anak bisa mendapatkan dunia yang lucu, indah, sederhana, dan nilai pendidikan yang menyenangkan melalui cerita sehingga tanpa dirasakan cerita menjadi efektif dalam menanamkan nilai moral dan edukasi pada anak.

Cerita merupakan rangkaian peristiwa yang disusun secara runtut dan berkesinambungan. Membuat cerita berseri berarti memuat sebagian peristiwa dan melanjutkan sebagian lain pada seri berikutnya. Cerita tersebut dilanjutkan dengan cara memecahkan peristiwa dengan memberikan solusi yang selaras pada seri selanjutnya. Selain itu, cerita dikatakan berseri apabila tokoh utama diperankan oleh tokoh-tokoh yang sama. Hal tersebut dilakukan dengan cara mempertahankan konsistensi ciri fisik, watak, dan kebiasaan tokoh utama pada setiap seri, menetapkan tokoh yang memulai peristiwa di awal seri ialah tokoh yang menuntaskan peristiwa di akhir seri, dan menegaskan tokoh utama memeroleh ganjaran yang setimpal di akhir seri sesuai dengan perbuatannya di seri-seri sebelumnya.

Salah satu nilai moral luhur yang dapat diperoleh dan diteladani anak ialah altruisme. Arifin (2015) mengemukakan bahwa altruisme adalah perhatian terhadap kesejahteraan orang lain tanpa memperhatikan diri sendiri. Penanaman nilai altruisme menjadi penting akhir-akhir ini mengingat terjadinya krisis moral yang membuat anak bangsa kehilangan kepekaan dan kepedulian terhadap sesama. Infiltrasi dapat dilihat dalam berbagai tayangan yang digandrungi remaja saat ini, yang hampir seluruhnya berpijak pada budaya asing dan tidak mencerminkan budaya Nusantara. Para generasi muda lebih tertarik pada budaya asing yang tidak memiliki nilai dan cerminan tingkah laku yang baik, sehingga banyak di antara generasi muda menampilkan perilaku yang kurang pantas. Akibatnya, para generasi muda penerus bangsa meninggalkan budaya asli yang sarat akan nilai luhur kehidupan (Rahmawati, 2018). Mengusung altruisme sebagai tema besar dalam cerita dirasa tepat untuk menghadapi krisis moral tersebut. Konsistensi penggunaan tema altruisme pada cerita berseri diharapkan dapat menumbuhkan nilai karakter peduli sosial secara intensif pada diri anak. 
Salah satu bentuk integrasi nilai altruisme dalam cerita anak ialah dengan mendatangkan tokoh anak yang mengabaikan kepentingan diri demi menolong orang-orang di lingkungan barunya. Melalui tokoh tersebut, anak diberi contoh altruisme. Contoh tersebut berfungsi sebagai stimulasi agar anak dapat mengembangkan kepekaan dan kepedulian sosial. Dengan pemberian stimulasi melalui indera visualnya, anak dapat belajar berempati terhadap lingkungan sosial di sekitarnya. Sikap peduli bukan hanya ditunjukkan pada manusia saja, tetapi juga pada semua makhluk yang ada dalam lingkungan sekitar kita, seperti hewan dan tumbuhan jika mereka membutuhkan pertolongan. Disisi lain, sikap belas kasih perlu dimiliki setiap anak agar memiliki kepekaan rasa terhadap lingkungan sekitarnya (Juanda, 2018).

Kekayaan nilai budaya dan tradisi yang terdapat dalam cerita rakyat Nusantara tidak sepenuhnya tepat untuk digunakan dalam pembelajaran. Cerita rakyat yang telah mentradisi di tengah masyarakat hingga sekarang ini tidak mengidahkan penggunaan bahasa yang sesuai untuk anak. Cerita rakyat dengan bahasa anak berarti cerita yang bebas dari unsur kekerasan dan seksualitas. Oleh sebab itu, menggunakan cerita rakyat Nusantara sebagai basis cerita anak tidak luput dari perhatian mengenai bahasa yang digunakan. Dengan bahasa yang tepat, wawasan nilai budaya dan tradisi daerah di Indonesia pada masa lampau akan lebih mudah dipahami dan dihayati anak.

Pengembangan cerita anak pernah dilakukan oleh Puspitasari (2017) tentang pengembangan buku cerita fantasi berbasis literasi sains. Keterkaitan penelitian ini dengan penelitian Puspitasari terletak pada penggunaan basis tertentu dalam mengembangkan produk cerita. Selain itu, Puspitasari juga mengembangkan buku cerita yang didasarkan pada hasil uji keterbacaan teks. Penelitian serupa dilakukan oleh Wachidah (2017) tentang pengembangan bahan bacaan cerita rakyat sebagai pembentuk literasi moral. Keterkaitan penelitian ini dengan penelitian Wachidah terletak pada jenis cerita yang dikembangkan, yaitu berupa cerita rakyat. Selain itu, produk berupa bahan bacaan cerita rakyat yang dikembangkan Wachidah juga berpedoman pada unsur isi, kebahasaan, dan tampilan yang layak untuk siswa. Penelitian lainnya dilakukan oleh Ali (2015) tentang pengembangan cerita fantasi untuk pendidikan karakter bagi anak usia dini. Keterkaitan penelitian ini dengan penelitian Ali terletak pada sasaran produk, yaitu anak-anak. Selain itu, produk cerita yang dikembangkan Ali juga memuat pendidikan karakter untuk anak-anak. Penelitian ini memiliki perbedaan dengan ketiga penelitian sebelumnya. Penelitian Puspitasari berbasis literasi sains, sedangkan penelitian ini berbasis cerita rakyat Nusantara. Penelitian pengembangan cerita rakyat dari Wachidah bertujuan untuk membentuk literasi moral siswa, sedangkan penelitian pengembangan ini bertujuan untuk membentuk karakter peduli sosial dan rasa empati dengan mengangkat altruisme sebagai tema besar. Penelitian pengembangan Ahli difokuskan bagi anak usia dini, sedangkan penelitian ini difokuskan bagi siswa sekolah menengah pertama.

Tujuan penelitian ini, yaitu (1) menghasilkan produk berupa buku cerita berseri dengan tema altruism untuk pembelajaran cerita rakyat yang dikembangkan dengan berpedoman pada kriteria unsur fiksional cerita, yaitu bertema altruisme, tokoh unik dan aneh, latar hutan dan kerajaan, serta alur maju, (2) menguji keterbacaan produk buku cerita berseri dengan tema altruisme untuk pembelajaran cerita rakyat, dan (3) menguji keefektifan produk buku cerita berseri dengan tema altruisme untuk pembelajaran cerita rakyat.

\section{METODE}

Penelitian ini menggunakan model penelitian dan pengembangan 4D (four D model) Thiagarajan, dkk. Model penelitian dan pengembangan 4D terdiri atas empat tahap, yaitu (1) pendefinisian, (2) perancangan, (3) pengembangan, dan (4) diseminasi. Tahap pendefinisian bertujuan untuk mendefinisikan ketentuan-ketentuan yang diperlukan dalam pembelajaran. Tahap pendefinisian, meliputi (1) analisis kebutuhan, (2) analisis siswa, (3) analisis tugas, (4) analisis konsep, (5) seleksi, dan (6) perumusan tujuan penelitian dan pengembangan. Tahap perancangan terdiri atas tujuh langkah, yaitu (1) penentuan tokoh dan watak tokoh, (2) penentuan latar, (3) penentuan alur, (4) penentuan amanat, (5) perancangan reorientasi, (6) perancangan komplikasi, dan (7) perancangan resolusi. Tahap pengembangan terdiri atas uji ahli dan uji coba terbatas. Tahap uji ahli dilakukan terhadap ahli materi dan praktisi. Tahap uji coba terbatas dilakukan terhadap siswa sekolah menengah pertama. Uji coba terhadap siswa dilakukan untuk mengetahui keterbacaan produk cerita sesuai dengan rumusan tujuan penelitian dan pengembangan. Tahap diseminasi tidak dilakukan karena membutuhkan jangkauan yang lebih luas.

Validasi produk dilakukan melalui dua tahap, yaitu uji ahli dan uji pelaksanaan lapangan. Uji ahli dilakukan oleh ahli materi cerita tradisional sebagai ahli 1 dan ahli psikologi perkembangan sebagai ahli 2. Uji pelaksanaan lapangan dilakukan pada praktisi dan siswa sekolah menengah pertama. Adapun lokasi validasi produk pada kelompok ahli dilakukan di Universitas Negeri Malang, sedangkan lokasi uji pelaksanaan lapangan pada praktisi dan siswa dilakukan di SMP Negeri 18 Malang. Subjek validasi produk terdiri atas dua kelompok, yaitu kelompok ahli (ahli materi cerita tradisional dan ahli psikologi perkembangan) dan kelompok lapangan (siswa sekolah menengah pertama).

Terdapat dua jenis data, yaitu data verbal dan data numerik. Data verbal dibedakan menjadi data verbal tertulis dan tidak tertulis. Data verbal tertulis berupa catatan, komentar, kritik, dan saran yang ditulis oleh ahli materi cerita tradisional, ahli psikologi perkembangan, dan praktisi pada kolom angket rubrik validasi dan coretan pada naskah produk. Data verbal tertulis lainnya, yaitu komentar yang ditulis oleh siswa pada kolom angket saat uji coba produk di lapangan. Data verbal tidak tertulis berupa informasi lisan yang berkenaan dengan saran dari ahli dan praktisi yang selanjutnya ditranskrip. Data numerik diperoleh dari skor uji validasi ahli materi cerita tradisional, ahli psikologi perkembangan, praktisi, dan uji pelaksanaan lapangan pada siswa sekolah menengah pertama. 
Instrumen yang digunakan, yaitu (1) angket validasi untuk ahli dan (2) angket uji pelaksanaan lapangan untuk siswa. Angket uji ahli materi cerita tradisional digunakan untuk mengetahui sejauh mana cerita yang dikembangkan sesuai dengan tujuan dan spesifikasi produk yang diharapkan. Angket uji ahli psikologi perkembangan digunakan untuk mengetahui sejauh mana cerita yang dikembangkan sejalan dengan perkembangan siswa. Angket uji pelaksanaan lapangan adalah angket yang digunakan untuk mengetahui sejauh mana cerita berseri yang dikembangkan memenuhi syarat keterbacaan. Keterbacaan berkaitan dengan kemudahan siswa dalam membaca jenis dan ukuran huruf, kata-kata, memahami ilustrasi dan alur peristiwa, serta menjawab latihan.

Rancangan eksperimen penelitian ini menggunakan true experimental design, yaitu kelompok kontrol pretest-posttest. Dalam rancangan ini terdapat dua kelompok yang dipilih secara random, yaitu kelompok eksperimen dan kelompok kontrol. Sebelum dikenai perlakuan diberi pretest dan setelah perlakuan selesai diberi posttest. Kelompok eksperimen diberikan perlakuan berupa implementasi buku cerita berseri dengan tema altruisme untuk pembelajaran cerita rakyat bagi siswa kelas VII SMP.

Teknik analisis data penelitian ini terdiri atas (1) teknik analisis data kualitatif dan (2) teknik analisis data kuantitatif. Teknik analisis data kualitatif dilakukan dengan cara mengumpulkan data verbal berupa catatan, komentar, kritik, dan saran dari ahli. Teknik analisis data kuantitatif dilakukan dengan cara mengolah data numerik dari angket ahli dan angket uji lapangan.

\section{HASIL}

Hasil uji produk meliputi (1) uji validasi, (2) uji coba lapangan, (3) uji keterbacaan, dan (4) uji keefektifan. Uji validasi dilakukan oleh dua ahli dan satu praktisi, yaitu (1) ahli materi cerita tradisional, (2) ahli psikologi perkembangan, dan (3) ahli praktisi. Ahli materi cerita tradisional dan praktisi menilai produk dari aspek unsur fiksional cerita, kebahasaan, dan kegrafikaan, sedangkan ahli psikologi perkembangan menilai produk dari aspek unsur fiksional. Data hasil validasi buku cerita dipaparkan pada tabel 1 .

Tabel 1. Data Hasil Validasi Buku Cerita

\begin{tabular}{cllccc}
\hline No. & \multicolumn{1}{c}{ Penguji } & Aspek yang diuji & $\begin{array}{c}\text { Persentase } \\
(\mathbf{\%})\end{array}$ & Kualifikasi & Tindak Lanjut \\
\hline 1 & Ahli Materi Cerita Tradisional & $\begin{array}{l}\text { Unsur fiksional cerita } \\
\text { Kebahasaan } \\
\text { Kegrafikaan }\end{array}$ & 90 & SL & I \\
\hline 2 & Ahli Psikologi Perkembangan & Unsur fiksional cerita & 75 & L & I \\
\hline 3 & Praktisi & $\begin{array}{l}\text { Unsur fiksional cerita } \\
\text { Kebahasaan } \\
\text { Kegrafikaan }\end{array}$ & 77 & L & I \\
\hline Rata-rata & & 81 & L & I \\
\hline
\end{tabular}

Keterangan:

$\begin{array}{ll}\text { L } & \text { : Layak } \\ \text { SL } & \text { : Sangat Layak } \\ \text { I } & \text { : Implementasi }\end{array}$

Data Hasil Uji Aspek Unsur Fiksional Cerita

Terdapat lima aspek unsur fiksional cerita yang diujikan kepada ahli materi, ahli psikologi, dan praktisi. Lima unsur fiksional tersebut, yaitu tema, tokoh, latar, alur, dan amanat. Data hasil uji aspek unsur fiksional cerita dipaparkan pada tabel 2.

Tabel 2. Data Hasil Uji Aspek Unsur Fiksional Cerita

\begin{tabular}{|c|c|c|c|c|c|}
\hline \multirow[t]{2}{*}{ No. } & \multirow{2}{*}{$\begin{array}{c}\text { Aspek yang diuji } \\
\text { Unsur Fiksional }\end{array}$} & \multicolumn{3}{|c|}{ Penilaian oleh Ahli } & \multirow[t]{2}{*}{ Tindak Lanjut } \\
\hline & & Materi & Psikologi & Praktisi & \\
\hline 1 & Tema & 94 & 75 & 75 & I \\
\hline 2 & Tokoh & 87 & 75 & 75 & I \\
\hline 3 & Latar & 75 & 75 & 75 & I \\
\hline 4 & Alur & 95 & 75 & 75 & I \\
\hline 5 & Amanat & 86 & 75 & 75 & I \\
\hline \multicolumn{2}{|c|}{ Rata-rata } & 87 & 75 & 75 & I \\
\hline
\end{tabular}

Dari tabel 2 diketahui bahwa dari kelima aspek unsur fiksional cerita, ahli materi memberikan persentase $>85 \%$ yang berarti produk berkualifikasi sangat layak, sedangkan ahli psikologi dan praktisi memberikan persentase $75 \%$ yang berarti berkualifikasi layak. Dari hasil validasi aspek unsur fiksional cerita, didapatkan rata-rata sebesar 79\% dengan kualifikasi layak dan tindak lanjut implementasi. Akan tetapi, ahli cerita anak tradisional memberikan saran untuk perbaikan produk. Ahli cerita 
anak tradisional menyarankan agar istilah-istilah Jawa diberikan catatan kaki agar tidak terdapat penafsiran ganda dari pembaca, terutama untuk pembaca yang tidak mengerti bahasa Jawa. Berdasarkan saran tersebut, diberikan catatan kaki pada bagian bawah teks untuk istilah-istilah Jawa yang terdapat dalam cerita.

\section{Data Hasil Uji Aspek Kebahasaan}

Uji aspek kebahasaan kepada ahli materi dan praktisi meliputi aspek komunikatif, imajinatif, sesuai perkembangan siswa, dan interaktif. Data hasil uji aspek unsur kebahasaan dipaparkan pada tabel 3.

Tabel 3. Data Hasil Uji Aspek Kebahasaan

\begin{tabular}{|c|c|c|c|c|}
\hline No. & Aspek yang diuji & \multicolumn{2}{|c|}{ Penilaian oleh Ahli } & Tindak Lanju \\
\hline \multicolumn{2}{|r|}{ Kebahasaan } & Materi & Praktisi & \\
\hline 1 & Komunikatif & 83 & 75 & I \\
\hline 2 & Imajinatif & 87 & 75 & I \\
\hline 3 & Sesuai perkembangan siswa & 92 & 75 & I \\
\hline 4 & Interaktif & 75 & 75 & I \\
\hline \multicolumn{2}{|c|}{ Rata-rata } & 84 & 75 & $\mathrm{I}$ \\
\hline
\end{tabular}

Dari tabel 3 diketahui bahwa dari keempat aspek kebahasaan, ahli materi dan ahli psikologi memberikan persentase $>75 \%$ yang berarti produk berkualifikasi layak. Dari hasil validasi aspek kebahasaan, didapatkan rata-rata sebesar $79 \%$ dengan kualifikasi layak dan tindak lanjut implementasi.

\section{Data Hasil Uji Aspek Kegrafikaan}

Uji aspek kegrafikaan kepada ahli materi dan praktisi, meliputi aspek ukuran buku, desain sampul, tipografi, ilustrasi, dan tata letak. Data hasil uji aspek kegrafikaan dipaparkan pada tabel 4.

Tabel 4. Data Hasil Uji Aspek Kegrafikaan

\begin{tabular}{|c|c|c|c|c|}
\hline \multirow[t]{2}{*}{ No. } & \multirow{2}{*}{$\begin{array}{l}\text { Aspek yang diuji } \\
\text { Kegrafikaan }\end{array}$} & \multicolumn{2}{|c|}{ Penilaian oleh Ahli } & \multirow[t]{2}{*}{ Tindak Lanjut } \\
\hline & & Materi & Praktisi & \\
\hline 1 & Ukuran Buku & 94 & 75 & I \\
\hline 2 & Desain Sampul & 94 & 75 & I \\
\hline 3 & Tipografi & 92 & 75 & I \\
\hline 4 & Ilustrasi & 94 & 75 & I \\
\hline 5 & Tata Letak & 92 & 75 & I \\
\hline \multicolumn{2}{|c|}{ Rata-rata } & 93 & 75 & I \\
\hline
\end{tabular}

Dari Tabel 4 diketahui bahwa dari kelima aspek kegrafikaan, ahli materi memberikan persentase $>85 \%$ yang berarti produk berkualifikasi sangat layak, sedangkan praktisi memberikan persentase $75 \%$ yang berarti berkualifikasi layak. Dari hasil validasi aspek kegrafikaan, didapatkan rata-rata sebesar 84\% dengan kualifikasi layak dan tindak lanjut implementasi.

\section{Uji Lapangan}

Uji lapangan dilakukan dengan meminta 30 siswa kelas 7H SMPN 18 Malang untuk mengisi angket. Angket tersebut berisi 12 pertanyaan yang mencakup aspek tampilan fisik produk, bahasa produk, isi produk, buku cerita, dan nilai moral. Data hasil uji coba lapangan buku cerita disajikan pada tabel 5.

Tabel 5. Data Hasil Uji Coba Lapangan Buku Cerita

\begin{tabular}{clccc}
\hline No. & Aspek yang diuji & Persentase $(\%)$ & Kualifikasi & Tindak Lanjut \\
\hline 1 & Tampilan fisik produk & 85 & SL & I \\
2 & Bahasa produk & 93 & SL & I \\
3 & Isi produk & 91 & SL & I \\
4 & Buku cerita & 87 & SL & I \\
5 & Nilai moral & 88 & SL & I \\
\hline \multicolumn{2}{l}{ Rata-rata } & 89 & SL & I \\
\hline
\end{tabular}


Dari Tabel 5 diketahui bahwa kelima aspek yang terdapat pada angket uji coba lapangan memeroleh persentase $>85 \%$ yang berarti produk berkualifikasi sangat layak dan tindak lanjut implementasi. Adapun rata-rata persentase hasil uji coba lapangan buku cerita, yaitu 89\% dengan kualifikasi sangat layak dan tindak lanjut implementasi.

\section{Uji Keterbacaan}

Uji keterbacaan dilakukan untuk mengetahui kategori teks termasuk sangat mudah, mudah, cukup mudah, kurang mudah, atau tidak mudah. Uji keterbacaan buku cerita dilakukan menggunakan skala linkert. Dalam skala tersebut, diberikan 10 pertanyaan. Data hasil uji keterbacaan buku cerita disajikan pada tabel 6.

Tabel 6. Data Hasil Uji Keterbacaan Buku Cerita

\begin{tabular}{clcc}
\hline No. & Judul Seri & Persentase (\%) & Katergori Teks \\
\hline 1 & Samas dan Raksasa Tiga Warna & 87 & Mudah \\
2 & Samas dan Si Bungsu Gunung Tenggara & 85 & Mudah \\
3 & Samas dan Burung Maleo Berkepala Dua & 86 & Mudah \\
4 & Samas dan Manusia-Manusia Batu & 90 & Mudah \\
\hline Rata-rata & 87 & Mudah \\
\hline
\end{tabular}

Dari Tabel 6 diketahui bahwa keempat seri Samas memeroleh persentase $<90 \%$ yang berarti teks seri Samas berkategori mudah. Rata-rata persentase hasil uji keterbacaan buku cerita, yaitu $87 \%$ yang berarti produk memiliki tingkat keterbacaan tinggi.

\section{Uji Keefektifan}

Prasyarat untuk melakukan uji keefektifan ialah uji normalitas dan uji homogenitas. Uji normalitas digunakan untuk mengetahui distribusi data normal atau tidak. Data normal merupakan syarat mutlak sebelum melakukan analisis statistik parametrik, yaitu uji paired sample t-test dan uji independent sample t-test. Uji normalitas yang digunakan, yaitu uji Kolmogorov-Smirnov dan uji Shapiro-Wilk. Data hasil uji normalitas disajikan pada tabel 7.

Tabel 7. Data Hasil Uji Normalitas

\begin{tabular}{|ll|r|r|r|r|r|r|}
\hline \multirow{2}{*}{ Kelas } & & \multicolumn{4}{|c|}{ Kolmogorov-Smirnov } & \multicolumn{3}{|c|}{ Shapiro-Wilk } \\
\cline { 3 - 8 } & Statistic & df & \multicolumn{1}{c|}{ Sig. } & Statistic & \multicolumn{1}{c|}{ df } & \multicolumn{1}{c|}{ Sig. } \\
\hline \multirow{3}{*}{ Hasil } & Pretest Kelas Kontrol &, 151 & 20 &, $200^{*}$ &, 975 & 20 &, 860 \\
belajar & Posttest Kelas Kontrol &, 151 & 20 &, $200^{*}$ &, 978 & 20 &, 900 \\
& Pretest Kelas Eksperimen &, 184 & 20 &, 076 &, 923 & 20 &, 115 \\
& Posttest Kelas Ekperimen &, 219 & 20 &, 103 &, 922 & 20 &, 108 \\
\hline
\end{tabular}

*. This is a lower bound of the true significance.

a. Lilliefors Significance Correction

Dari tabel 7 diketahui bahwa nilai signifikansi pretest kelas kontrol $>0,05$, yaitu 0,200. Hal itu berarti distribusi data adalah normal. Dari tabel di atas diketahui bahwa nilai signifikansi posttest kelas kontrol $>0,05$, yaitu 0,200 . Hal itu berarti distribusi data adalah normal. Dari tabel di atas diketahui bahwa nilai signifikansi pretest kelas eksperimen >0,05, yaitu 0,076 . Hal itu berarti distribusi data adalah normal. Dari tabel di atas diketahui bahwa nilai signifikansi posttest kelas kontrol $<0,05$, yaitu 0,103 . Hal itu berarti distribusi data adalah normal. Uji homogenitas digunakan untuk mengetahui sama tidaknya variansivariansi dua buah distribusi atau lebih. Data hasil uji homogenitas disajikan pada tabel 8.

Tabel 8. Data Hasil Uji Homogenitas

\begin{tabular}{|c|c|c|c|}
\hline \multicolumn{4}{|c|}{ Hasil Belajar } \\
\hline Levene Statistic & df1 & df2 & Sig. \\
\hline ,400 & 3 & 76 &, 753 \\
\hline
\end{tabular}

Dari tabel 8 diketahui bahwa nilai signifikansi $>0,05$, yaitu 0,753 . Hal itu berarti distribusi data adalah homogen. Setelah mengetahui bahwa syarat data normal dan homogen terpenuhi, maka selanjutnya dilakukan uji keefektifan. Uji keefektifan dilakukan dengan analisis statistik parametrik, yaitu uji paired sample t-test dan uji independent sample t-test. Uji paired sample t-test digunakan untuk mengetahui apakah terdapat perbedaan rata-rata dua sampel berpasangan. Dua sampel yang dimaksud adalah sampel yang sama namun mempunyai dua data. Data hasil uji paired sample t-test disajikan pada tabel 9. 
Tabel 9. Data Hasil Uji Paired Sample T-Test

\begin{tabular}{|c|c|c|c|c|c|c|c|c|}
\hline & \multicolumn{5}{|c|}{ Paired Differences } & \multirow[t]{3}{*}{$\mathrm{t}$} & \multirow[t]{3}{*}{$\mathrm{df}$} & \multirow{3}{*}{$\begin{array}{l}\text { Sig. (2- } \\
\text { tailed) }\end{array}$} \\
\hline & \multirow[t]{2}{*}{ Mean } & \multirow[t]{2}{*}{$\begin{array}{c}\text { Std. } \\
\text { Deviation }\end{array}$} & \multirow{2}{*}{$\begin{array}{c}\text { Std. } \\
\text { Error } \\
\text { Mean }\end{array}$} & \multicolumn{2}{|c|}{$\begin{array}{c}95 \% \text { Confidence Interval } \\
\text { of the Difference }\end{array}$} & & & \\
\hline & & & & Lower & Upper & & & \\
\hline $\begin{array}{ll} & \text { Hasil } \\
\text { Pair 1 } & \text { belajar - } \\
& \text { Kelas }\end{array}$ & 87,05000 & 3,89384 & ,43535 & 86,18347 & 87,91653 & 199,956 & 79 &, 000 \\
\hline
\end{tabular}

Dari tabel 9 diketahui bahwa nilai signifikansi (2-tailed) $<0,05$, yaitu 0,000. Hal itu berarti terdapat perbedaan yang signifikan antara kelas kontrol dan kelas eksperimen. Uji independent sample t-test digunakan untuk mengetahui apakah terdapat perbedaan rata-rata data sampel yang tidak berpasangan. Data hasil uji independent sample t-test disajikan pada Tabel 10 .

Tabel 10. Data Hasil Uji Independent Sample T-Test

\begin{tabular}{|c|c|c|c|c|c|c|c|c|c|c|}
\hline & \multicolumn{2}{|c|}{$\begin{array}{c}\text { Levene's } \\
\text { Test for } \\
\text { Equality of } \\
\text { Variances }\end{array}$} & \multicolumn{7}{|c|}{ t-test for Equality of Means } \\
\hline & & \multirow[t]{2}{*}{$\mathrm{F}$} & \multirow[t]{2}{*}{ Sig. } & \multirow[t]{2}{*}{$\mathrm{t}$} & \multirow[t]{2}{*}{ df } & \multirow[t]{2}{*}{$\begin{array}{l}\text { Sig. (2- } \\
\text { tailed) }\end{array}$} & \multirow[t]{2}{*}{$\begin{array}{c}\text { Mean } \\
\text { Difference }\end{array}$} & \multirow[t]{2}{*}{$\begin{array}{l}\text { Std. Error } \\
\text { Difference }\end{array}$} & \multicolumn{2}{|c|}{$\begin{array}{l}\text { 95\% Confidence } \\
\text { Interval of the } \\
\text { Difference }\end{array}$} \\
\hline & & & & & & & & & Lower & Upper \\
\hline & $\begin{array}{l}\text { Equal } \\
\text { variances } \\
\text { assumed }\end{array}$ &, 075 & ,786 & $-2,446$ & 38 & ,019 & $-2,50000$ & 1,02225 & $-4,56944$ &,- 43056 \\
\hline belajar & $\begin{array}{l}\text { Equal } \\
\text { variances } \\
\text { not } \\
\text { assumed }\end{array}$ & & & $-2,446$ & 37,862 & ,019 & $-2,50000$ & 1,02225 & $-4,56969$ &,- 43031 \\
\hline
\end{tabular}

Dari tabel 10 diketahui bahwa nilai signifikansi (2-tailed) <0,05, yaitu 0,019. Hal itu berarti terdapat perbedaan yang signifikan antara kelas kontrol dan kelas eksperimen.

\section{Revisi}

Revisi produk dilakukan berdasarkan saran yang diberikan oleh ahli cerita anak tradisional, ahli psikologi perkembangan, dan praktisi. Ahli cerita anak tradisional dan ahli psikologi perkembangan menyarankan agar istilah-istilah Jawa diberikan catatan kaki agar tidak terdapat penafsiran ganda dari pembaca, terutama untuk pembaca yang tidak mengerti bahasa Jawa. Berdasarkan saran tersebut, diberikan catatan kaki pada bagian bawah teks untuk istilah-istilah Jawa yang terdapat dalam cerita.

Ahli materi cerita anak tradisional memberikan saran lain terkait gaya penceritaan. Gaya penceritaan yang digunakan dalam cerita masih menggunakan gaya penceritaan orang dewasa. Karena sasaran buku cerita ialah siswa SMP, maka cerita perlu menggunakan gaya penceritaan anak-anak. Oleh sebab itu, gaya penceritaan perlu direvisi agar lebih memusatkan cerita dengan menggunakan gaya penceritaan anak-anak. Ahli materi cerita anak tradisional, ahli psikologi perkembangan, dan praktisi menyarankan agar dalam cerita disertakan ilustrasi untuk menghidupkan cerita dan lebih membantu pembaca memahami cerita. Oleh sebab itu, perlu ditambahkan ilustrasi dalam cerita. Masing-masing seri cerita disertakan lima ilustrasi bewarna.

\section{PEMBAHASAN}

Penelitian ini menghasilkan produk berupa buku cerita seri Samas. Terdapat empat judul cerita seri Samas, yaitu (1) Samas dan Raksasa Tiga Warna, (2) Samas dan Si Bungsu Gunung Tenggara, (3) Samas dan Burung Maleo Berkepala Dua, dan (4) Samas dan Manusia-Manusia Batu. Buku cerita seri Samas berkaitan dengan kesetiakawanan dan solidaritas dalam persahabatan. Tokoh anak dalam buku cerita seri Samas dilepas dari dominasi orang tua melalui petualangannya ke tempat baru. Tokoh anak tersebut membuat keputusan, menghadapi musuh, dan menerima pujian atas keberhasilannya. Tokoh anak juga diberikan kesan hebat dengan menyelesaikan konflik yang rumit untuk melawan secara sengit tokoh antagonis yang berkarakter kompleks. 


\section{Isi Cerita}

Isi produk cerita seri Samas memiliki lima aspek cerita, yaitu (1) tema, (2) tokoh, (3) latar, (4) alur, dan (5) amanat. Berikut dipaparkan kelima aspek tersebut.

Pertama, tema cerita. Tema buku cerita berseri Samas ialah altruisme. Altruisme merupakan perilaku menolong orang lain tanpa memikirkan kepentingan sendiri. Tema merupakan ide dasar cerita yang terwadahi dalam keseluruhan unsur cerita (Nurhadi, 2017). Tema juga mengandung pelajaran untuk membangun karakter luhur pembacanya. Menurut Norton (1983), karakteristik cerita tradisional dilihat dari segi tema, yaitu memuat kebenaran universal yang berisi harapan tertinggi manusia, seperti moral dan pencapaian material, yang merefleksikan nilai tradisional masyarakat (watak, aksi, penghargaan, dan hukuman). Nilai-nilai budaya seperti rendah hati, kebaikan, kesabaran, simpati, kerja keras, dan keberanian yang diekspresikan dalam cerita rakyat selalu dihargai. Hal ini dilatarbelakangi adanya keinginan untuk mendapatkan imbalan yang setimpal dalam hidup, yaitu berumur panjang, suami yang baik atau istri yang penuh kasih, rumah yang indah dan pakaian bagus, banyak makanan, kebebasan dari rasa takut terhadap raksasa. Kekuatan cinta, belas kasih, kebaikan adalah salah satu tema utama dari cerita rakyat (Huck, 1987). Dengan mengangkat altruisme secara konsisten sebagai tema cerita, diharapkan rasa empati dan peduli dapat menguat dalam diri anak. Sears, dkk. (1985) menyatakan bahwa altruisme ialah tindakan sukarela yang dilakukan seseorang atau sekelompok orang untuk menolong orang lain tanpa mengharapkan imbalan apapun (kecuali mungkin perasaan telah melakukan kebaikan).

Kedua, tokoh dan penokohan. Dalam cerita seri Samas, tokoh berupa anak muda, raksasa, anak bungsu, hewan yang aneh, dan penyihir. Cerita seri Samas memiliki tiga tokoh utama yang berkawan, yaitu Samas, Tamma, dan Andamari. Samas berwatak cerdas, pemberani, dan suka menolong. Tamma memiliki watak kuat, gemar berbagi, dan humoris. Andamari memiliki watak ramah, selalu ceria, dan berempati tinggi. Karakter yang baik terdiri atas mengetahui hal yang baik, menginginkan hal yang baik dan melakukan hal yang baik, kebiasaan dalam cara berpikir, kebiasaan dalam hati, dan kebiasaan dalam tindakan. Internalisasi pendidikan karakter akan efektif dan memiliki makna jika anak didik tidak saja paham tentang kebaikan, tetapi juga menjadikan kebaikan itu sebagai sikap dan sifat, serta termanifestasikan dalam laku dan tindak kehidupan sehari-hari (Junaini, 2017). Pengembangan karakter di dalam cerita, yaitu pengembangan tokoh (characters) dan penokohan (characterization) mengkonstruk pemahaman dan meningkatkan kecerdasan moral dan emosional siswa sehingga lebih jujur, lebih peka, lebih disiplin dan bertanggung jawab (Pratiwi, 2017). Tokoh yang terdapat pada cerita dongeng atau fabel merupakan tokoh berupa benda atau binatang yang bersikap layaknya manusia, tetapi sikap dan pengetahuannya didasarkan pada anak-anak (Kurniawan, 2014). Karakteristik cerita tradisional dilihat dari segi tokoh, yaitu tokoh yang berkarakter baik terdiri atas pahlawan muda, anak bungsu, peri, hewan yang aneh, dan kurcaci, sedangkan tokoh yang berkarakter buruk terdiri atas raksasa, penyihir, dan ibu tiri (Norton, 1983).

Ketiga, latar cerita. Latar seri Samas dibagi menjadi tiga, yaitu latar tempat, waktu, dan suasana. Latar tempat serial Samas ialah Negeri Para Penolong, hutan belantara, kerajaan, tanah lapang, Gunung Tenggara, dan danau. Latar waktu serial Samas ialah masa lampau yang terdiri atas dini hari, pagi hari, petang, dan tengah malam. Latar suasana serial Samas ialah menegangkan, mengharukan, menyedihkan, menakutkan, dan membahagiakan. Menurut Norton (1983), karakteristik cerita tradisional dilihat dari segi latar, yaitu bertempat di dalam hutan gelap dan kerajaan ajaib, sedangkan waktunya di masa lampau. Latar berfungsi sebagai pembangkit tanggapan atau suasana tertentu dalam cerita (Nurgiyantoro, 1995).

Keempat, alur cerita. Bagian awal berisi deskripsi dan informasi awal cerita yang berisi pengenalan tokoh, keadaan, dan kejadian yang akan menjadi sumber permasalahan cerita, baik bersifat implisit maupun eksplisit (Kurniawan, 2013). Stewig (1980) mengungkapkan bahwa karakteristik cerita tradisional memiliki alur yang ringkas, sederhana, alur langsung, dan jarang mengikutsertakan subalur. Pada pengenalan umum, digambarkan waktu lampau yang tidak ditentukan, sedangkan tempat dideskripsikan sedikit dan tidak spesifik/samar. Pada bagian kesimpulan, diberikan kesimpulan yang menonjol, memuaskan, dan tegas. Tegas menurut Stewig berarti lepas dari kesulitan dan seringkali cerita berakhir dengan bahagia.

Kelima, amanat. Kepribadian dan kemanusiaan anak yang meliputi: kepekaan sosial, religi, kehalusan rasa, pembangunan nilai, moral, dan budi pekerti menjadi terolah dan terasah melalui cerita (Aziz, 2014). Cerita rakyat yang kaya akan nilai-nilai moral dapat dijadikan sarana komunikasi untuk mengajarkan nilai-nilai pendidikan tentang kehidupan kepada masyarakat (Gusnetti, 2015). Cerita anak dimuat dalam pembelajaran bahasa dan satra Indonesia di sekolah sebagai salah satu aspek keterampilan apresiasi sastra dimana siswa dituntut untuk mampu mengapresasi sastra sehingga nilai-nilai positif yang terkandung di dalamnya dapat terserap (Islamy, 2016). Moral dalam sebuah cerita dapat dipahami sebagai suatu sarana yang berkaitan dengan ajaran moral yang terkandung dalam cerita atau sengaja dimaksudkan oleh pengarang untuk disampaikan kepada pembaca lewat cerita yang bersangkutan (Roysa, 2017).

Rekaan cerita dilakukan oleh pencerita dengan mencari hubungan yang sedang diceritakan dengan sesuatu yang terjadi di alam atau penanda yang dapat diliat di alam. Dari cerita itu, pencerita memasukan unsur-unsur moral, agama, politik, dan budaya serta unsur-unsur pendidikan yang dapat diserap dan dapat dipahami oleh anak guna menanamkan nilai-nilai atau unsur moral tersebut (Gusal, 2015). Sikap dan perilaku tokoh yang ada dalam cerita rakyat dapat diteladani moralnya. Moral para tokoh yang ada dalam cerita tercermin pada sikap tanggung jawab, disiplin, kerja sama, kepedulian, kejujuran, gotong royong, dan kerja keras. Hal tersebut mengarah pada pendidikan karakter yang dapat dijadikan sebagai pondasi pembentukan karakter pada diri manusia (Kristanto, 2014). 


\section{Kebahasaan, Kegrafikaan, dan Ilustrasi}

Karakteristik bahasa yang digunakan pada buku cerita ini mempertimbangkan karakteristik kemampuan bahasa siswa kelas 6-8 yang dikemukakan oleh Omrod dan Santrock. Karakteristik tersebut, meliputi (1) memiliki pengetahuan sebanyak sekitar 50.000 kata, (2) telah mampu memahami kalimat-kalimat yang kompleks, dan (3) adanya kesadaran mengenali terminologi yang digunakan dalam berbagai disiplin ilmu (Omrod, 2008). Selain itu, anak-anak umur 11-12 tahun telah dapat menggunakan bahasa dengan cara yang lebih terhubung, memproduksi wacana terhubung, dan mampu mengubungkan kalimat satu sama lain untuk menghasilkan deskripsi, definisi, dan narasi yang masuk akal (Santrock, 2014 ).

Kegrafikaan buku cerita seri Samas mengikuti standar penulisan buku yang dikeluarkan oleh BSNP. Standar untuk komponen kelayakan kegrafikan meliputi (1) ukuran buku, (2) bagian kulit buku, dan (3) bagian isi buku.

Pertama, ukuran buku. Untuk ukuran buku, buku cerita seri Samas menggunakan format buku A5, yaitu 14,8x21 cm. Format ini sesuai dengan format ISO, yaitu A4 (21x29,7cm), A5 (14,8x21 cm), B5 (18,2x25,7cm) dengan toleransi 5-20 mm. Adapun kualitas kertas menggunakan kertas yang berkualitas, yaitu Power Mac G4. Selain itu, buku cerita seri Samas juga dijilid dengan kualitas jilidan yang baik dan kuat. Hal ini dimaksudkan agar kertas tidak mudah sobek atau rusak.

Kedua, bagian kulit buku. Pada bagian kulit buku, buku cerita seri Samas telah dibuat menarik dan ilustratif. Pemilihan warna dan ilustrasi sampul mempunyai kualitas tinggi sehingga gambar dan warna tidak pecah, bersih, dan jelas ketika dicetak.

Ketiga, bagian isi buku. Bagian isi buku cerita seri Samas di-layout oleh ahli sehingga buku ini mudah dibaca baik dari segi jenis fontasi, warna fontasi, maupun ukuran fontasi. Format buku cerita seri Samas menggunakan font dengan ukuran 12 pt. Format fontasi ini sesuai dengan standar BSNP. Untuk judul, ukuran fontasi telah disesuaikan dengan kebutuhan. Hal ini sesuai dengan pendapat Sihombing (2001:63) yang menyatakan bahwa untuk naskah yang panjang, apabila huruf dicetak terlalu kecil akan cepat melelahkan mata atau bahkan mungkin akan sukar dibaca. Namun, apabila dicetak terlalu besar akan mengganggu estetika rancangan. Oleh sebab itu, ukuran fontasi untuk isi teks dan judul sampul dipilih berbeda.

Dalam buku cerita seri Samas disertakan ilustrasi cerita. Ilustrasi dan teks cerita secara bersamaan membentuk perpaduan, saling mendukung, dan tidak berdiri sendiri. Pernyataan ini sejalan dengan pendapat (Sutherland, 1973) yang menyatakan bahwa beberapa cerita bisa benar-benar hilang dengan diceritakan tanpa ilustrasi yang menyertainya. Hal senada juga diungkapkan oleh Salinger (1996) yang menyatakan bahwa illustrations complement and enhance the short text and carry much of the message. Ilustrasi melengkapi dan meningkatkan teks pendek dan membawa pesan. Penulis lain yang menyatakan bahwa ilustrasi dalam buku anak itu penting ialah Arleen. Dalam tulisannya, Arleen berpendapat bahwa lewat ilustrasi, otak anak mulai dilatih untuk membuat hubungan antara teks dan gambar. Pentingnya ilustrasi juga disampaikan oleh Iser melalui artikel penelitian yang ditulisnya. While reading Tom Jones, they may never have had a clear conception of what the hero actually looks like, but on seeing the film, some may say, 'that's not how I imagined him'. Dari keempat pendapat tersebut dapat disimpulkan bahwa dalam cerita penting untuk disertakan ilustrasi agar dapat menghidupkan cerita dan lebih membantu pembaca memahami cerita.

Adapun ilustrasi yang baik adalah ilustrasi (1) menangkap dan mempertahankan ketertarikan pembaca dan (2) mempunyai seni pembeda yang bekerja dengan teks untuk mendukung cerita (Cullinan, 1989). Dengan merujuk pendapat Cullinan tersebut, letak dan jumlah ilustrasi dalam buku cerita seri Samas juga disesuaikan agar pembaca tidak jenuh dengan teks cerita. Pendapat lain mengenai kemenarikan ilustrasi juga disampaikan oleh Wollman. Children admired the illustrations and wondered out load how Schoenherr had created pictures that made them feel 'like you are there, like you can really see it' or 'like you are up high looking down on them' (Wollman, 1995). Wollman berpendapat bahwa ilustrasi yang menarik adalah ilustrasi yang mampu membuat anak-anak seolah berada di dalam cerita dan seolah benar-benar melihatnya. Selain itu, ilustrasi didesain dengan pewarnaan yang dikombinasikan dengan hijau, putih, dan cokelat sebagai daya beda dan ciri khas tanah dan kesuburan Nusantara. Fungsi dari gambar-gambar yang diilustrasikan tersebut adalah mendorong imajinasi anak untuk memahamkan dan mengembangkan alur cerita yang berupa narasi teks pada buku yang dibaca.

Masing-masing seri cerita disertakan lima ilustrasi bewarna. Adapun kelima gambar ilustrasi pada produk buku cerita dibuat secara bervariasi, yaitu berada di sela-sela teks, di bagian bawah atau atas teks, dan di halaman samping teks satu halaman penuh. Gambar pada buku seri Samas ditata dengan memerhitungkan aspek keindahan tampilan, kemenarikan, dan secara mudah mata anak beralih dari teks ke gambar dan dari gambar ke teks. Oleh sebab itu, perlu untuk memperhatikan panduan mengevaluasi ilustrasi supaya ilustrasi berperan maksimal dalam cerita.

Ilustrasi yang digunakan harus sesuai dengan apa yang diceritakan dan mampu membangkitkan citraan atau imaji secara hidup dan kaya agar bacaan anak menarik. Selain itu, kemenarikan juga ditentukan dari frekuensi dan ukuran gambar ilustrasi yang digunakan. Oleh karena sasaran dari buku cerita seri ini adalah anak-anak remaja awal yang berada di kelas VII SMP, maka frekuensi gambar tidak sering muncul dan ukuran gambar yang dibuat juga tidak terlalu besar. Frekuensi dan ukuran gambar yang digunakan merujuk dari pendapat Pusposari. Anak-anak ini sudah tidak lagi tertarik pada tampilan fisik, melainkan lebih memperhatikan isi cerita (Pusposari, 2012:6). Gambar di buku-buku anak yang lebih besar sering lebih kecil menempati separuh halaman kanan, kiri, atau bawah, belum tentu bewarna, dan belum tentu berada di setiap halaman kanan dan kiri Anak yang berada di kelas tinggi atau jenjang di atasnya lagi, sudah mulai memahami cerita degan frekuensi penggunaan gambar mulai berkurang. 
Gambar yang diilustrasikan mengungkap momen dramatik yang esensial dari adegan cerita, bebas dari kekejaman, kekerasan, dan seksualitas. Hal ini telah sesuai dengan pendapat Ellis (1973) yang menyatakan bahwa cerita anak bebas dari kekejaman, kekerasan, dan seksualitas. Selain itu, adegan yang diilustrasikan juga bukan adegan yang tak bermakna. Hal ini didukung dengan pendapat Taryadi (1999) yang menyatakan bahwa adegan yang diilustrasikan dalam sastra anak merupakan adegan yang vital, signifikan, dan mengungkap momen-momen dramatik yang penting. Oleh sebab itu, pada buku cerita seri Samas hanya dipilih lima adegan yang vital dan dramatik yang perlu untuk diilustrasikan.

\section{Buku Panduan Implementasi Guru}

Buku panduan implementasi disusun mulai dari sampul, kata pengantar, daftar isi, dan isi buku. Isi buku panduan terdiri atas (1) karakteristik dan (2) petunjuk penggunaan. Karakteristik memuat kompetensi inti, kompetensi dasar, indikator, sasaran, dan pengertian cerita berseri dan cerita rakyat. Pada bagian petunjuk penggunaan terdapat waktu pelaksanaan, petunjuk penggandaan, petunjuk pembagian kelompok, metode pembelajaran, langkah-langkah pembelajaran, sifat tes, pelaksanaan tes: cara pengerjaan, urutan pengerjaan, dan pengumpulan, serta penggunaan rubrik penilaian. Buku panduan implementasi berukuran A5 dengan pilihan fontasi Times New Roman yang diketik dengan ukuran 12 pt. Buku panduan dikombinasi dengan warna hijau dan putih agar kontras dengan buku cerita berseri yang dikembangkan.

\section{SIMPULAN}

Buku cerita berseri dengan tema altruisme untuk pembelajaran cerita rakyat bagi siswa kelas VII SMP merupakan produk yang dikembangkan dengan berpedoman pada kriteria unsur fiksional cerita, yaitu bertema altruisme, tokoh unik dan aneh, latar hutan dan kerajaan, serta alur maju. Setiap seri buku tersebut telah melalui uji validasi, uji keterbacaan, dan uji keefektifan produk.

Pertama, uji validasi. Uji validasi dilakukan pada ahli cerita tradisional, ahli psikologi perkembangan, dan ahli praktisi. Berdasarkan hasil uji validasi terhadap buku cerita, diperoleh rata-rata mencapai $81 \%$ dengan kualifikasi layak dan tindak lanjut implementasi. Dengan demikian, disimpulkan bahwa produk siap untuk diimplementasikan.

Kedua, uji keterbacaan. Uji keterbacaan empat seri buku cerita dilakukan pada siswa SMP kelas VII di SMP 18 Malang. Dari hasil uji keterbacaan dapat diketahui bahwa produk buku cerita berseri ini memiliki kategori mudah dengan skor mencapai $87 \%$. Dengan demikian, disimpulkan bahwa produk memiliki tingkat keterbacaan tinggi.

Ketiga, uji keefektifan. Uji keefektifan buku cerita berseri dilakukan dengan mengukur indikator-indikator yang berhasil dicapai pada kompetensi dasar mengidentifikasi isi cerita dan menelaah struktur dan kebahasaan cerita. Berdasarkan hasil uji normalitas dan hasil uji homogenitas, diketahui bahwa distribusi data adalah normal dan homogen. Berdasarkan hasil uji paired sample t-test dan hasil uji independent sample $t$-test, diketahui bahwa terdapat perbedaan yang signifikan antara kelas kontrol dan kelas eksperimen. Dari hasil uji paired sample t-test dan independent sample t-test, disimpulkan bahwa produk efektif digunakan dalam pembelajaran cerita rakyat.

Berdasarkan hasil uji validasi, keterbacaan, dan juga keefektifan, produk berkualifikasi layak, memiliki tingkat keterbacaan tinggi, dan juga efektif digunakan dalam pembelajaran. Oleh sebab itu, disarankan kepada guru bahasa Indonesia untuk dapat memanfaatkan buku cerita berseri ini sebagai bacaan penunjang dalam pembelajaran cerita rakyat bagi siswa Kelas VII SMP. Selain itu, produk buku cerita berseri ini juga dapat dimanfaatkan oleh pendongeng sebagai bahan untuk bercerita. Peneliti lain juga dapat memanfaatkan buku cerita berseri ini sebagai sumber referensi untuk penelitian sejenis.

Produk buku cerita berseri ini telah melalui (1) uji validasi dengan hasil kualifikasi layak dan siap implementasi, (2) uji keterbacaan dengan hasil teks berkategori tingkat keterbacaan tinggi, dan (3) uji keefektifan dengan hasil produk efektif digunakan dalam pembelajaran cerita rakyat. Dengan demikian, produk buku cerita berseri ini dapat didiseminasi. Diseminasi dilakukan melalui empat cara, yaitu (1) MGMP, (2) sosialisasi di sekolah, (3) internet, dan (4) penerbitan. Pertama, para guru yang tergabung dalam forum MGMP dapat memeroleh produk yang dikemas dalam bentuk buku elektronik melalui praktisi yang menguji produk. Kedua, produk dapat digandakan untuk disosialisasikan di sekolah tempat uji produk. Ketiga, produk dapat diunggah dengan memanfaatkan media internet. Keempat, produk dapat diterbitkan setelah mendapatkan ISBN. Cara keempat tidak dilakukan karena membutuhkan cakupan yang lebih luas.

Produk buku cerita ini dikembangkan dengan jenis cerita berupa legenda dan dongeng, mencakup empat basis cerita rakyat Nusantara, bertema altruisme dengan sasaran pembaca siswa SMP kelas VII, dan hanya dikembangkan sebanyak empat seri cerita. Peneliti lain dapat mengembangkan produk buku cerita berseri ini lebih lanjut. Pengembangan produk lebih lanjut dapat dilakukan dengan memilih jenis cerita berupa fabel, mitos, atau epos. Peneliti lain juga dapat menggunakan cakupan basis cerita rakyat Nusantara yang lebih luas, seperti Kancil, Si Pitung, atau Keong Mas. Pengembangan produk lebih lanjut juga dapat dilakukan dengan memilih tema lain yang dekat siswa, yaitu heroisme. Selain itu, sasaran pembaca dapat ditujukan untuk anak-anak usia sekolah dasar atau remaja akhir yang menempuh pendidikan di SMA sederajat. Peneliti lain juga dapat mengembangkan produk ini lebih lanjut dengan membuat seri cerita yang lebih beragam, misalnya lima hingga enam seri atau lebih. 


\section{DAFTAR RUJUKAN}

Ali, M. (2015). Pengembangan Cerita Fiksi untuk Pendidikan Karakter bagi Anak Usia Dini. Tesis tidak diterbitkan. UIN Sunan Kalijaga, Yogyakarta.

Arifin, B. S. (2015). Psikologi Sosial. Bandung: Pustaka Setia.

Arleen. (2018). Belajar Menulis Cerita Anak. Jakarta: Erlangga.

Aziz, A. (2014). Fabel sebagai Bahan Pembelajaran Bahasa dan Sastra Indonesia di Sekolah Dasar. Jurnal Paramasastra, 1(2).

Gusal, L. O. (2015). Nilai-Nilai Pendidikan dalam Cerita Rakyat Sulawesi Tenggara Karya La Ode Sidu. Jurnal Humanika, $3(15)$.

Gusnetti., Syofiani., \& Isnanda, R. (2015) Struktur dan Nilai-Nilai Pendidikan dalam Cerita Rakyat Kabupaten Tanah Datar Provinsi Sumatera Barat. Jurnal Gramatika, 1(2), 183-192.

Islamy, A. N., Sumardi., \& Apriliya, S. (2016). Cerita Anak Karya Mahasiswa PGSD UPI Kampus Tasikmalaya Berdasarkan Kriteria Pemilihan Bahan Ajar Cerita di SD. PEDADIDAKTIKA: Jurnal Ilmiah Pendidikan Guru Sekolah Dasar, 3(1), 17-23.

Juanda. (2018). Revitalisasi Nilai Dalam Dongeng sebagai Wahana Pembentukan Karakter Anak Usia Dini. Jurnal Pustaka Budaya, 5(2).

Junaini, E., Agustina, E., \& Canrhas, A. (2017). Analisis Nilai Pendidikan Karakter dalam Cerita Rakyat Seluma. Jurnal Korpus, 1(1).

Kristanto, M. (2014). Pemanfaatan Cerita Rakyat sebagai Penanaman Etika untuk Membentuk Pendidikan Karakter Bangsa. Mimbar Sekolah Dasar, 1(1), 59-64.

Kurniawan, H. (2009). Sastra Anak dalam Kajian Strukturalisme, Sosiologi, Semiotika, hingga Penulisan Kreatif. Yogyakarta: Graha Ilmu.

McGee, L. M., \& Tompkins, G. E. (1995). Literature-Based Reading Instruction: What's Guiding the Instruction?. Language Arts, 72, 405-414.

Nurgiyantoro, B. (1995). Teori Pengkajian Fiksi. Yogyakarta: Gadjah Mada University Press.

Nurhadi. (2017). Handbook of Writing. Jakarta: PT Bumi Aksara.

Pratiwi, N. L. M. T. (2017). Pengembangan Buku Cerita Anak dengan Menginsersi Budaya Lokal dalam Tema Kegemaranku untuk Kelas I Sekolah Dasar. Jurnal Ilmiah Pendidikan dan Pembelajaran, 1(3), 185-195.

Puspitasari, A. (2017). Pengembangan Buku Cerita Fantasi Berbasis Literasi Sains pada Siswa SMP Kelas VII di Kota Malang . Tesis tidak diterbitkan. Universitas Negeri Malang, Malang.

Pusposari, D. (2012). Memahami Sastra Anak. Malang: Bayumedia Publishing.

Rahmawati, F. E. (2018). Revitalisasi Cerita Panji dalam Wayang Beber. Jurnal Studi Budaya Nusantara, 2(1), 34-41. DOI: http://dx.doi.org/10.21776/ub.sbn.2018.002.01.04

Roysa, M. (2017). Analisis Buku Bacaan Anak "Belajar Sambil Berternak Ayam” berdasarkan Pendekatan Stuktural. Jurnal Kredo: Jurnal Ilmah Bahasa dan Sastra, 1(1), 18-30. DOI: https://doi.org/10.24176/kredo.v1i1.1750

Sihombing, D. (2003). Tipografi: dalam Desain Grafis. Jakarta: Gramedia Pustaka Utama.

Stewig, J. W. (1980). Children and Literature. Boston: Houghton Mifflin Company.

Sutherland, Z., \& May, H. A. (1991). Children and Books. New York: Harper Collins Publisher.

Taryadi, A. (1999). Buku dalam Indonesia Baru: Editor dan Kata Pengantar. Jakarta: Yayasan Obor Indonesia.

Wachidah, L. R. (2017). Pengembangan Bahan Bacaan Cerita Rakyat sebagai Pembentuk Literasi Moral bagi Siswa Kelas VII $S M P / M t S$. Tesis tidak diterbitkan. Universitas Negeri Malang, Malang.

Wollman-Bonilla, J. E. \& Werchadlo, B. (1995). Literature Response Journals in a First Grade Classroom. Language Arts, $72(8), 562-570$ 